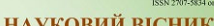

Sientific messenger of Lviv National University

2.

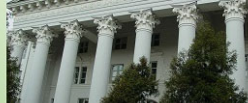

1.

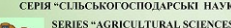

Том 22 № 93 2020
Науковий вісник Дьвівського національного університету ветеринарної медицини та біотехнологій імені С.3. Гжицького. Серія: Сільськогосподарські науки

Scientific Messenger of Lviv National University of Veterinary Medicine and Biotechnologies. Series: Agricultural sciences

\title{
Properties of formed compositions of probiotic strains isolated from Carpathian bryndza
}

\author{
I. I. Kushnir ${ }^{1}$, O. Y. Tsisaryk ${ }^{1}$, I. M. Kushnir ${ }^{2}$, I. S. Semen ${ }^{2}$, I. M. Slyvka ${ }^{1}$, L. Y. Musiy ${ }^{1}$ \\ ${ }^{I}$ Stepan Gzhytskyi National University of Veterinary Medicine and Biotechnologies Lviv, Lviv, Ukraine \\ ${ }^{2}$ State Scientific-Research Control Institute of Veterenary Medicinal Products and Feed Additives, Lviv, Ukraine
}

\section{Article info}

Received 07.09.2020

Received in revised form 08.10 .2020

Accepted 09.10.2020

Stepan Gzhytskyi National University of Veterinary Medicine and Biotechnologies Lviv, Pekarska Str., 50, Lviv,

79010, Ukraine.

Tel: $+38-098-29-01-694$

E-mail: irynakushn@gmail.com

State Scientific-Research Control Institute of Veterenary Medicinal Products and Feed Additives, Donetsk Str., 11, Lviv 79010, Ukraine.
Kushnir, I. I., Tsisaryk, O. Y., Kushnir, I. M., Semen, I. S., Slyvka, I. M., \& Musiy, L. Y. (2020). Properties of formed compositions of probiotic strains isolated from Carpathian bryndza. Scientific Messenger of Lviv National University of Veterinary Medicine and Biotechnologies. Series: Agricultural sciences, 22(93), 119-125. doi: 10.32718/nvlvet-a9320

In order to give the product functional properties, promising for the industry strains of cultures of lactic acid bacteria L. lactis ssp. lactis IMAU 32258, Lb. plantarum KLDS 1.0728 and E. durans SB18, isolated from traditional Carpathian bryndza. It was found that under conditions of co-cultivation, the studied strains were compatible, ie did not show interspecific antagonism. Based on these probiotic strains, five compositions of L. lactis ssp. lactis IMAU 32258, Lb. plantarum KLDS 1.0728 and E. durans SB18 in the ratios,\%: composition № 1 - 50:25:25; № 2 - 33:33:33; № 3 - 50:40:10; № 4 - 50:10:40 and № 5 70:15:15 respectively. When determining the rate of biomass accumulation, it was found that at a temperature of $32{ }^{\circ} \mathrm{C}$ the highest growth intensity was registered in the cultivation of compositions № 1, № 2 and № 4, it exceeded the control by 19.5-20.1 times $(P<0.001)$. At a temperature of $37^{\circ} \mathrm{C}$ for $24 \mathrm{~h}$, the highest change in the optical density of the nutrient medium was found in the cultivation of compositions № 1, № 2 and № 3, in particular, it increased, respectively, in 17.9, 17.8 and $18.1(P<0.001)$ times compared to control. When determining the ability of different compositions of the consortium of lactic acid bacteria to reduce the $\mathrm{pH}$ of the medium, it was found that for $24 \mathrm{~h}$ of cultivation at $32{ }^{\circ} \mathrm{C}$ the best acidforming properties showed compositions № 3, № 4 and № 5 because they reduced the $\mathrm{pH}$ of the medium by $32.8,33.3$ and $32.8 \%$, respectively, to 4.87-4.91 units. At a temperature of $37{ }^{\circ} \mathrm{C}$ formed by us compositions were able to reduce the $\mathrm{pH}$ of the medium to 5.03-5.12 units, while the best acid-forming properties showed compositions № 1, № 3 and № 5. In determining the antagonistic properties of the studied compositions of microorganisms when cultured at temperature $32{ }^{\circ} \mathrm{C}$ was found to have moderate antagonistic activity against Escherichia coli, Enterobacter aerogenes, Proteus mirabilis, Salmonella enteritidis, Staphylococcus aureus and Pseudomonas aeruginosa, ie against all cultures of pathogenic and opportunistic microorganisms. Compared with other compositions, composition № 3 showed the highest antagonistic activity against Staphylococcus aureus, as well as quite high against Salmonella enteritidis, Pseudomonas aeruginosa and Enterobacter aerogenes. When culturing the studied compositions of a consortium of microorganisms at a temperature of $37^{\circ} \mathrm{C}$, all compositions showed moderate antagonistic activity against all test cultures of pathogenic and opportunistic microorganisms. Composition № 3 showed slightly higher antagonistic activity against Staphylococcus aureus, Salmonella enteritidis, Enterobacter aerogenes, as well as at a temperature of $32{ }^{\circ} \mathrm{C}$, as well as against Pseudomonas aeruginosa. Therefore, isolated from traditional Carpathian cheese L. lactis ssp. lactis IMAU 32258, Lb. plantarum KLDS 1.0728 and $E$. durans $S B 18$ have a high degree of biocompatibility and are suitable in different ratios for use in one composition, as indicated by the ability to accumulate biomass, lower $\mathrm{pH}$ and antagonistic activity to pathogenic and opportunistic microflora.

Key words: Enterococcus durans, Lactococcus lactis, Lactobacillus plantarum, antagonistic activity, optical density, $\mathrm{pH}$ of the medium. 


\title{
Властивості сформованих композицій пробіотичних штамів, виділених із карпатської бринзи
}

\author{
I. І. Кушнір ${ }^{1}$, О. Й. Цісарик ${ }^{1}$, І. М. Кушнір ${ }^{2}$, І. С. Семен ${ }^{2}$, І. М. Сливка ${ }^{1}$, Л. Я. Мусій ${ }^{1}$ \\ ${ }^{1}$ Львівський національний університет ветеринарної медицини та біотехнологій імені С. 3. Гэсииького, м. Львів, \\ Україна \\ ${ }^{2}$ Державний науково-дослідний контрольний інститут ветеринарних препаратів та кормових добавок, \\ м. Львів, Украӥна
}

\begin{abstract}
Для надання продукту функиіональних властивостей, було використано перспективні для промисловості штами культур молочнокислих бактерій L. lactis ssp. lactis IMAU 32258, Lb. plantarum KLDS 1.0728 та E. durans SB18, виділені з традиџійної карпатської бринзи. Встановлено, що за умов спільного культивування досліджувані штами були сумісні, тобто не проявляли міжвидового антагонізму. На основі ичих пробіотичних штамів створили п'ять композицій L. lactis ssp. lactis IMAU 32258, Lb. plantarum KLDS 1.0728 ma E. durans SB18 у співвідношеннях, \%: композиція № 1 - 50:25:25; № 2 - 33:33:33; № 3 - 50:40:10; № 4 - 50:10:40 та № 570:15:15 відповідно. При визначенні швидкості накопичення біомаси встановили, що за температури $32{ }^{\circ} \mathrm{C}$ вища інтенсивність росту зареєстрована при культивуванні композицій № 1, № 2 та № 4, вона переважала контроль у 19,5-20,1 рази (P<0,001). 3a температури $37{ }^{\circ} \mathrm{C}$ на 24 год вищу зміну оптичної густини живильного середовища встановлено при культивуванні композицій № 1, № 2 та № 3, зокрема, вона зростала, відповідно у 17,9, 17,8 та 18,1 (P <0,001) рази порівняно до контролю. При визначенні здатності різних композицій консориіуму молочнокислих бактерій знижувати рН середовища, встановили, що на 24 год культивування за температури $32{ }^{\circ} \mathrm{C}$ кращі кислотоутворювальні властивості проявили композиції № 3, № 4 та № 5, оскільки знижували рН середовища на 32,8, 33,3 та 32,8 \% відповідно, до 4,87-4,91 одиниць. За температури $37{ }^{\circ}$ С сформовані нами композииії були здатні знижувати рН середовища до 5,03-5,12 одинищь, при иььму кращі кислотоуворювальні властивості проявили композиціі № 1, № 3 та № 5. При визначенні антагоністичних властивостей досліджуваних композицій мікроорганізмів при культивуванні за температури $32{ }^{\circ} \mathrm{C}$ встановили, що вони проявили помірну антагоністичну активність до Escherichia coli, Enterobacter aerogenes, Proteus mirabilis, Salmonella enteritidis, Staphylococcus aureus ma Pseudomonas aeruginosa, тобто до усіх тест культур патогенних та умовно-патогенних мікроорганізмів. Порівняно з іншими композиціями, композиція № 3 проявила найвищу антагоністичну активність до Staphylococcus aureus, а також досить високу до Salmonella enteritidis, Pseudomonas aeruginosa i Enterobacter aerogenеs. При культивуванні досліджуваних композицій консориіуму мікроорганізмів за температури $37^{\circ} \mathrm{C}$ усі композицї̈ проявили помірну антагоністичну активність щодо усіх тест-культур патогенних та умовно-патогенних мікроорганізмів. Композиція № 3 проявила дещо вищу антагоністичну активність щодо Staphylococcus aureus, Salmonella enteritidis, Enterobacter aerogenes, як $i$ за температури $32{ }^{\circ} \mathrm{C}$, а також щодо Pseudomonas aеruginosa. Отже, виділені з традииійної карпатської бринзи L. lactis ssp. lactis IMAU 32258, Lb. plantarum KLDS 1.0728 ma E. durans SB18 володіють високим ступенем біосумісності та придатні у різних співвідношеннях до використання їх у одній композииї, на що вказує здатність до накопичення біомаси, зниження рН середовища та прояв антагоністичної активності до патогенної та умовно-патогенної мікрофлори.
\end{abstract}

Ключові слова: Enterococcus durans, Lactococcus lactis, Lactobacillus plantarum, антагоністична активність, оптична густина, рН середовища.

\section{Вступ}

Біотехнологія посідає важливе місце у переробці тваринної сировини, оскільки за їі допомогою створюються нові види продукції. При цьому особлива увага приділяється селекції штамів за важливими біотехнологічними показниками, зокрема такими як: стабільність, високі ростові властивості штамів, молокозсідальна активність та енергія кислотоутворення, здатність до синтезу біологічно активних речовин тощо. Розвиток сучасного ринку потребує розширення асортименту ферментованих молочних та м'ясних продуктів, що досягається пошуком нових та ефективних промислових пробіотичних штамів мікроорганізмів (Danylenko et al., 2019).

Необхідно зазначити, що міжнародні стандарти висувають певні вимоги до відбору пробіотичних штамів, штами повинні бути виділені від здорових людей або тварин. Пробіотичні штами не повинні бути вірулентними, токсигенними, токсичними, не продукувати ферменти, що відносяться до факторів патогенності (каталазу, гіалуронідазу, фібринолізин, гемолізин, лецитиназу). Крім того, вони повинні бути стійкими до дії факторів травного тракту - низьких значень $\mathrm{pH}$, жовчних кислот, ферментів, проявляти антагоністичну активність, продукувати ферменти, вітаміни, кислоти, бактеріоцини, бактеріостатини тощо, мати високу швидкість росту та розмноження, а при конструюванні комплексних препаратів необхідно всебічно обгрунтовати підбір штамів (Ganguly et al., 2011; Hoffmann et al., 2012; Kalinichenko et al., 2016).

3 огляду на це, видовий склад мікроорганізмів, які використовуються для отримання пробіотиків, постійно розширюється і представлений різноманітними видами, зокрема Escherichia coli, Lactobacillus, Bifidobacterium, Streptococcus, Lactococcus, Enterococcus, Propionibacterium, Leuconostoc, Aerococcus, Saccharomyces, Bacillus, Pediococcus, Streptococcus, Clostridium тощо (Voida \& Solonyna, 2012; Solonyna, 2013).

Найчастіше в якості пробіотичних штамів використовують біфідо і молочнокислі бактерії. Такі пробіотики отримали назву класичні, оскільки мікроорганізми, що входять до їх складу вже з перших днів життя домінують у різних біотопах макроорганізму (Vamanu \& Vamanu, 2010). Молочнокислі бактерії храктеризуються високою колонізаційною здатністю та синтезом біологічно активних речовин, що, у свою чергу, слугує захисним бар'єром для потрапляння патогенної мікрофлори i, таким чином, забезпечується стабілізація нормального складу мікробіоценозу та підвищується неспецифічна резистентність організму 
(Martinez et al., 2011). Крім того, кисле середовище сприяє кращому засвоєнню клітинами жирів, вітамінів, іонів заліза і кальцію (Irkitova, 2012).

При конструюванні різних пробіотичних та заквашувальних препаратів однією із головних вимог $\epsilon$ антагоністична активність пробіотичних штамів до патогенних та умовно-патогених мікроорганізмів (Vasyliuk et al., 2014; Merlich \& Limanska, 2016). Meханізм антагоністичної дії пов'язують з утворенням органічних кислот, пероксиду водню та різних антибіотичних речовин, які спричиняють протимікробну дію на ріст та розвиток сторонньої мікрофлори (Pokhylko \& Kravchenko, 2016). Тому, дуже часто молочнокислі бактерії широко використовуються у різних галузях, зокрема у харчовій промисловості (Bodnarchuk, 2012), гуманній та ветеринарній медицині (Huzhvynska, 2014). При цьому необхідно відбирати культури, що характеризуються високим ступенем антагонізму до патогенної та умовно-патогенної мікрофлори і водночас вони повинні бути сумісними 3 іншими представниками молочнокислих бактерій (Shuhai, 2015).

Молочнокислі бактерії відіграють основну роль у виробництві кисломолочних продуктів, де виконують функції трансформації лактози, білків, цитратів зумовлюючи специфічні органолептичні показники (Krasnykova et al., 2013). Особливо важливою властивістю молочнокислих бактерій є здатність зброджувати лактозу з утворенням молочної кислоти. Власне, внаслідок нагромадження молочної кислоти відбуваються зміни структури казеїнів, що призводять до зсідання молока і утворення згустку (Aween et al., 2012).

Для виробництва кисломолочних напоїв, твердих сичужних сирів, функціональних продуктів біотехнологія дає можливість отримання одно- і багатокомпонентних заквасок, бактеріальних концентратів як для збагачення, так і для ферментування молочної та м'ясної сировини. Цьому, у значній мірі, сприяє наявність широкого спектру пробіотичних штамів з різними біологічними властивостями (Danylenko et al., 2019).

Необхідно зазначити, що сьогодні у зв'язку з формуванням стійких до дії пробіотиків мікроорганізмів є потреба у створенні нових пробіотичних препаратів та заквасок (Skybitskyi et al., 2013).

Перспективним напрямком удосконалення пробіотиків $є$ розробка комплексних препаратів, до складу яких входять різні види бактеріальних культур, які взаємодоповнюють один одного за специфічною активністю та впливом на умовнопатогенні мікроорганізми (Huzhvynska, 2014).

Тому метою роботи було підібрати оптимальний склад молочнокислих бактерій з метою розроблення бактеріального препарату для виготовлення ферментованих молочних продуктів.

\section{Матеріал і методи досліджень}

3 метою визначення ефективної комплексної пробіотичної закваски створили композицію молочнокислих бактерій, виділених із традиційної карпатської бринзи, у різних співвідношеннях (Slyvka et al., 2018). Зокрема, композицію № 1 складали: Lactococcus lactis ssp.lactis IMAU 32258, Lactobacillus plantarum KLDS 1.0728 ma Enterococcus durans SB18 y співвідношенні 50:25:25; композицію № 2 складали у співвідношенні 33:33:33; композицію № 3 у співвідношенні - 50:40:10; композицію № 4 у співвідношенні - 50:10:40 та композицію № 5 у співвідношенні - 70:15:15 відповідно.

Для визначення здатності вказаних композицій мікроорганізмів знижувати кислотність середовища та встановлення швидкості їх росту (за зміною оптичної густини живильного середовища) проводили їх культивування у рідкому МРС. 3 цією метою досліджувані культури культивували на твердому МРС за температури $37{ }^{\circ} \mathrm{C}$ упродовж 18-20 год. Після чого стерильним ізотонічним розчином Натрію хлориду проводили змиви i готували завись мікроорганізмів на 0,5 одиниць за стандартом McFarlend. У колби із рідким живильним середовищем МРС вносили змиви культур L. lactis IMAU 32258, Lb. plantarum KLDS 1.0728 та E. durans SB18 у вказаних співідношеннях. Досліджувані проби культивували за температури 32 та $37{ }^{\circ} \mathrm{C}$ упродовж 24 год. Визначення $\mathrm{pH}$ середовища проводили потенціометричного за допомогою $\mathrm{pH}$ метра Master LAB. Оптичну густину середовища культивування визначали за допомогою приладу КФК-3 при довжині хвилі 590 нм.

Для встановлення антагоністичної активності культури підібраних композицій засівали у рідке середовище MPC (Himedia, Індія) та культивували упродовж 24 год за температури 32 та $37{ }^{\circ} \mathrm{C}$, після чого культуральну рідину центрифугували при 3000 об/хв упродовж 10 хв і фільтрували через мембранні фільтри Minisart, діаметром 0,22 мкм.

Чашки Петрі, які містили $25 \mathrm{~cm}^{3}$ МРС агару, засівали суспензією відповідних тест-культур умовнопатогенних мікроорганізмів (Escherichia coli, Salmonella enteritidis, Enterobacter aerogenes, Proteus mirabilis, Staphylococcus aureus, Pseudomonas aeruginosa) у концентрації $1 \times 10^{6} \mathrm{KУO} / \mathrm{cm}^{3}$ i витримували 1 год за температури $37^{\circ} \mathrm{C}$. Після цього у середовищі спеціальним профламбованим свердлом діаметром 6 мм робили лунки, які заповнювали отриманим супернатантом різних композицій в обємі 100 мкл. Чашки витримували упродовж 2 год (для дифузії супернатанту), а потім інкубували в аеробних умовах упродовж 24 год за температури $37^{\circ} \mathrm{C}$.

Антагоністичну активність досліджуваних штамів оцінювали за діаметром зон затримки росту умовнопатогенних мікроорганізмів навколо лунок. Штами вважалися неактивними при утворенні зони затримки росту 0-5 мм, мало активними - 5-10 мм, помірно активними - 11-20 мм, більше 20 мм високоактивними.

Всі дослідження проводили у трьох повтореннях, статистичну обробку даних проводили, використовуючи пакети програм "Exsel" та “STATISTICA 7,0”. Відмінності між величинами вважали достовірними при $\mathrm{P} \leq 0,05$.

Сумісність досліджуваних штамів L. lactis IMAU 32258, Lb. plantarum KLDS 1.0728 та E. durans SB18 
визначали за відстроченим антагонізмом (Egorov, 1965).

\section{Результати та їх обговорення}

Біотехнологія пробіотичних препаратів та заквасок направлена на стабілізування технологічного процесу та підвищення пробіотичних властивостей готового продукту за рахунок продукування мікроорганізмами біологічно активних речовин. Для підвищення ефективності пробіотичних препаратів використовують багатовидові консорціуми бактерій, при цьому вони повинні бути максимально спорідненими до біоценозу людини. 3 огляду на це, для надання продукту функціональних властивостей було використано перспе- ктивні для промисловості культури молочнокислих бактерій $L$. lactis IMAU 32258, Lb. plantarum KLDS 1.0728 та E. durans SB18, виділені з традиційної карпатської бринзи. У попередніх дослідженнях встановлено, що штам E. durans SB18 3-посеред ентерококів, ізольованих із традиційної карпатської бринзи, проявив добрі ростові, кислотоутворювальні та антагоністичні властивості (Kushnir et al., 2020) та здатність синтезувати біологічно активні речовини (Kushnir et al., 2020).

За умов спільного культивування лактобактерій надзвичайно важливим $є$ встановлення їх сумісності. Так, було встановлено, що досліджувані штами молочнокислих бактерій не проявили міжвидового антагонізму (табл. 1).

\section{Таблиця 1}

Сумісність пробіотичних штамів L. lactis IMAU 32258, Lb. plantarum KLDS 1.0728 та E. durans SB18

\begin{tabular}{lccc}
\hline Tест-штами & Lb. plantarum KLDS 1.0728 & L. lactis IMAU 32258 & E. durans SB18 \\
\hline Lb. plantarum KLDS 1.0728 & $\mathrm{x}$ & - & - \\
L. lactis IMAU 32258 & - & $\mathrm{x}$ & - \\
E. durans SB18 & - & - & $\mathrm{x}$ \\
\hline
\end{tabular}

Примітка: “-”- відсутність зон затримки росту мікроорганізмів

Для підтвердження можливості сумісного культивування молочнокислих бактерій дослідили інтенсивність накопичення біомаси, активність кислотоутворення та антагоністичні властивості до патогенної та умовно-патогенної мікрофлори. При спільному культивуванні композицій мікроорганізмів було визначено швидкість їх росту за зміною оптичної густини за температури 32 та $37{ }^{\circ} \mathrm{C}$ (табл. 2). Так, за температури $32{ }^{\circ} \mathrm{C}$ вища інтенсивність росту встановлена при культивуванні композицій № 1, № 2 та № 5. У попередніх дослідженнях нами встановлено, що за цієї температури штам E. durans SB18 демонстрував високу інтенсивність росту самостійно, вона переважала контроль у 17,9 рази (Kushnir et al., 2020). За температури $37{ }^{\circ} \mathrm{C}$ на 24 год вищу зміну оптичної густини живильного середовища спостерігали при культивуванні композицій № 1, № 2 та № 3, зокрема вона зростала, відповідно, у 17,9, 17,8 та 18,1 ( порівняно до контролю. Порівнюючи зміну оптичної густини середовища, при культивуванні E. durans SB18 самостійно за температури $37{ }^{\circ} \mathrm{C}$ (Kushnir et al., 2020), було встановлено, що оптична густина середовища зростала у 17,6 рази, тоді як за використання консорціуму мікроорганізмів у композиції № 1 , № 2 та № 3 була вищою, відповідно на 1,6, 1,1 та 2,8 \%.

Таблиця 2

Зміна оптичної густини середовища за культивування різних композицій консорціуму мікроорганізмів за різних температурних режимів

\begin{tabular}{lcc}
\hline \multirow{2}{*}{ Композиції } & \multicolumn{2}{c}{ Оптична густина, одиниці } \\
\cline { 2 - 3 } & $32^{\circ} \mathrm{C}$ & $37^{\circ} \mathrm{C}$ \\
\hline Контроль & $0,103 \pm 0,0002$ & $0,104 \pm 0,0002^{* * *}$ \\
Композиція № 1 (50:25:25) & $2,012 \pm 0,0044^{* * *}$ & $1,863 \pm 0,0013^{* * *}$ \\
Композиція № 2 (33:33:33) & $2,072 \pm 0,0031^{* * *}$ & $1,855 \pm 0,0010^{* * *}$ \\
Композиція № 3 (50:40:10) & $1,561 \pm 0,0019^{* * *}$ & $1,885 \pm 0,0014^{* * *}$ \\
Композиція № 4 (50:10:40) & $2,049 \pm 0,0025^{* * *}$ & $1,796 \pm 0,0006^{* * *}$ \\
Композиція № 5 (70:15:15) & $1,857 \pm 0,0012^{* * *}$ & $1,837 \pm 0,0036^{* * *}$ \\
\hline
\end{tabular}

Примітка: ***- $\mathrm{P}<0,001$

При визначенні здатності різних композицій L. lactis IMAU 32258, Lb. plantarum KLDS 1.0728 та E. durans $\mathrm{SB} 18$ знижувати $\mathrm{pH}$ середовища, отримали дані (табл. 3), які вказують на те, що на 24 год культивування за температури $32{ }^{\circ} \mathrm{C}$ кращі кислотоутворювальні властивості проявили композиції № 3, № 4 та № 5, оскільки знижували $\mathrm{pH}$ середовища на $32,8,33,3$ та 32,8 \%, відповідно, до 4,87-4,91 одиниць. За темпе- ратури $37^{\circ} \mathrm{C}$ сформовані композиції були здатними знижувати $\mathrm{pH}$ середовища до 5,03-5,12 одиниці, при цьому кращі кислотоуворювальні властивості проявили композиції № 1, № 3 та № 5. Порівнюючи кислототворювальну здатність композицій за різних температур, звертає на себе увагу кращий іiі прояв для всіх композицій за температури $32^{\circ} \mathrm{C}$. 
Таблиця 3

Зміна $\mathrm{pH}$ середовища за культивування різних композицій консорціуму мікроорганізмів за різних температурних режимів

\begin{tabular}{|l|c|c|}
\hline \multirow{2}{*}{ Композиції } & \multicolumn{2}{|c|}{$\mathrm{pH}$ середовища } \\
\cline { 2 - 3 } & $3{ }^{\circ} \mathrm{C}$ & $37^{\circ} \mathrm{C}$ \\
\hline Контроль & $7,31 \pm 0,0012$ & $7,34 \pm 0,0032^{* * *}$ \\
\hline Композиція № 1 (50:25:25) & $4,93 \pm 0,002^{* * *}$ & $5,03 \pm 0,002^{* * *}$ \\
\hline Композиція № 2 (33:33:33) & $4,92 \pm 0,0024 * * *$ & $5,06 \pm 0,0037^{* * *}$ \\
\hline Композиція № 3 (50:40:10) & $4,91 \pm 0,002^{* * *}$ & $5,03 \pm 0,0024^{* * *}$ \\
\hline Композиція № 4 (50:10:40) & $4,87 \pm 0,0045^{* * *}$ & $5,12 \pm 0,002^{* * *}$ \\
\hline Композиція № 5 (70:15:15) & $4,91 \pm 0,002^{* * *}$ & $5,05 \pm 0,002^{* * *}$ \\
\hline
\end{tabular}

Примітка: $* * *-\mathrm{P}<0,001$

При визначенні антагоністичних властивостей досліджуваних композицій пробіотичних штамів при культивуванні за температури $32{ }^{\circ} \mathrm{C}$ (табл. 4) встановили, що вони володіли помірною антагоністичною активністю до усіх тест культур патогенних та умовно-патогенних мікроорганізмів. При цьому, композиції № 1, № 2 та № 5 проявили дещо меншу активність щодо Salmonella enteritidis, в той час як композиція № 3 проявила найвищу антагоністичну активність до Staphylococcus aureus, досить високу активність порівняно $з$ іншими композиціями вона проявила і щодо Salmonella enteritidis, Pseudomonas aeruginosa i Enterobacter aerogenes.

\section{Таблиця 4}

Антагоністична активність різних композицій консорціуму мікроорганізмів за температури культивування $32{ }^{\circ} \mathrm{C}$

\begin{tabular}{lccccc}
\hline \multirow{2}{*}{ Тест-штами мікроорганізмів } & \multicolumn{5}{c}{ Композиції } \\
\cline { 2 - 6 } & № 1 & № 2 & № 3 & № 4 & № 5 \\
\hline E. coli & $50: 25: 25$ & $33: 33: 33$ & $50: 40: 10$ & $50: 10: 40$ & $70: 15: 15$ \\
S.enteritidis & $14,3 \pm 0,3$ & $14,6 \pm 0,3$ & $12,6 \pm 0,3$ & $14,3 \pm 0,3$ & $12,3 \pm 0,3$ \\
E. aerogenes & $10,6 \pm 0,3$ & $10,3 \pm 0,3$ & $13,6 \pm 0,3$ & $13,6 \pm 0,3$ & $10,6 \pm 0,3$ \\
P. mirabilis & $11,6 \pm 0,3$ & $11,6 \pm 0,3$ & $12,3 \pm 0,3$ & $12,3 \pm 0,3$ & $11,3 \pm 0,3$ \\
S. aureus & $11,3 \pm 0,3$ & $11,6 \pm 0,3$ & $11,6 \pm 0,3$ & $11,6 \pm 0,3$ & $11,3 \pm 0,3$ \\
P. aeruginosa & $11,3 \pm 0,3$ & $12,6 \pm 0,3$ & $14,3 \pm 0,3$ & $13,6 \pm 0,3$ & $10,6 \pm 0,3$ \\
& $11,6 \pm 0,3$ & $12,3 \pm 0,3$ & $12,6 \pm 0,3$ & $11,6 \pm 0,3$ & $12,6 \pm 0,3$ \\
\hline
\end{tabular}

При культуваванні досліджуваних композицій консорціуму мікроорганізмів за температури $37{ }^{\circ} \mathrm{C}$ (табл. 5) встановлено, що вони усі володіли також помірною антагоністичною активністю щодо усіх тест-культур патогенних та умовно-патогенних мікроорганізмів. Щодо Salmonella enteritidis всі композиції володіли дещо нижчою антагоністичною активністю, за винятком композиції № 3, де вона була найвищою. Найвищу антагоністичну активність для цієї композиції також зареєстровано і щодо Pseudomonas aeruginosa $i$ Staphylococcus aureus. Необхідно зазначити, що попередніми дослідженнями (Kushnir et al., 2020) було встановлено, що E. durans SB18, який входить до досліджуваних композицій, за 24 год культивування лише за температури $37{ }^{\circ} \mathrm{C}$ проявляв помірну антагоністичну активність до досліджуваних тест-мікоорганізмів, за винятком S. aureus.

\section{Таблиця 5}

Антагоністична активність різних композицій консорціуму мікроорганізмів за температури культивування $37^{\circ} \mathrm{C}$

\begin{tabular}{|c|c|c|c|c|c|}
\hline \multirow[b]{2}{*}{ Тест-штами мікроорганізмів } & \multicolumn{5}{|c|}{ Композиції } \\
\hline & $\begin{array}{c}\text { № } 1 \\
\text { 50:25:25 }\end{array}$ & $\begin{array}{c}\text { № } 2 \\
33: 33: 33 \\
\end{array}$ & $\begin{array}{c}\text { № } 3 \\
\text { 50:40:10 }\end{array}$ & $\begin{array}{c}\text { № } 4 \\
\text { 50:10:40 }\end{array}$ & $\begin{array}{c}\text { № } 5 \\
70: 15: 15\end{array}$ \\
\hline E. coli & $13,3 \pm 0,3$ & $14,3 \pm 0,3$ & $12,6 \pm 0,3$ & $13,3 \pm 0,3$ & $11,6 \pm 0,3$ \\
\hline S.enteritidis & $10,3 \pm 0,3$ & $10,6 \pm 0,3$ & $12,3 \pm 0,3$ & $10,6 \pm 0,3$ & $10,3 \pm 0,3$ \\
\hline E. aerogenes & $11,6 \pm 0,3$ & $11,6 \pm 0,3$ & $12,3 \pm 0,3$ & $11,3 \pm 0,3$ & $11,6 \pm 0,3$ \\
\hline P. mirabilis & $11,3 \pm 0,3$ & $12,3 \pm 0,3$ & $11,6 \pm 0,3$ & $12,6 \pm 0,3$ & $12,3 \pm 0,3$ \\
\hline S. aureus & $10,3 \pm 0,3$ & $11,3 \pm 0,3$ & $11,6 \pm 0,3$ & $10,3 \pm 0,3$ & $10,6 \pm 0,3$ \\
\hline P. aeruginosa & $12,3 \pm 0,3$ & $12,3 \pm 0,3$ & $13,6 \pm 0,3$ & $11,3 \pm 0,3$ & $11,6 \pm 0,3$ \\
\hline
\end{tabular}

Отже, за спільного культивування різних композицій консорціуму пробіотичних мікроорганізмів за температур 32 та $37^{\circ} \mathrm{C}$ було встановлено, що всі ком- позиції володіли помірною активністю щодо досліджуваних тест-культур патогенних та умовнопатогенних мікроорганізмів. Однак, звертає на себе 
увагу найвищий прояв антагоністичної активності композиції № 3 щодо Staphylococcus aureus, а також досить високий щодо Salmonella enteritidis, Pseudomonas aeruginosa i Enterobacter aerogenes, як за температури $32{ }^{\circ} \mathrm{C}$, так і за $37^{\circ} \mathrm{C}$.

\section{Висновки}

Виділені з традиційної карпатської бринзи L. lactis IMAU 32258, Lb. plantarum KLDS 1.0728 та E. durans SB18 володіють високим ступенем біосумісності та придатні в різних співвідношеннях до використання ïx у одній композиції, на що вказує здатність до накопичення біомаси, зниження $\mathrm{pH}$ середовища та прояв антагоністичної активності до патогенної та умовно-патогенної мікрофлори та відсутність міжвидового антагонізму. Встановлено, що композиція L. lactis IMAU 32258, Lb. plantarum KLDS 1.0728 та $E$. durans SB18 у співідношенні 50:40:10 за температури культивування 32 та $37^{\circ} \mathrm{C} \in$ найоптимальнішою для залучення іiі до пробіотичного препарату.

\section{References}

Aween, M. M., Hassan, Z., Muhialdin, B. J. Noor, H. M., \& Eljamel, Y. A. (2012). Evaluation on antibacterial activity of Lactobacillus acidophilus strains isolated from honey. American Journal of Applied Sciences, 9(6), 807-817. doi: 10.3844/ajassp.2012.807.817.

Bodnarchuk, O. V. (2012). Doslidzhennia antahonistychnoi aktyvnosti zakvasok dlia kyslovershkovoho masla. Naukovyi visnyk LNUVMBT im. S. Z. Hzhytskoho, 14, 252), 189-194 (in Ukrainian).

Danylenko, S. H., Naumenko, O. V, \& Potemska, O. I. (2019). Biotekhnolohiia yak osnova suchasnykh innovatsiinykh tekhnolohii vyrobnytstva prodovolchykh tovariv. Zhurnal Prodovolchi resursy, 12, 64-73. doi: 10.31073/foodresources2019-12-07 (in Ukrainian),

Egorov, N. S. (1965). Mikroby-antagonisty i biologycheskie metody opredelenija antibioticheskoj aktivnosti. M.: Vysshaja shkola (in Russian).

Ganguly, N. K., Bhattacharya, S. K., Sesikeran, B. et. al. (2011). ICMR-DBT Guidelines for evaluation of probiotics in food. Indian J Med Res 134(1), 22-25. URL: $\quad$ https://www.ncbi.nlm.nih.gov/pmc/articles/ PMC3171912.

Hoffmann, D. E. et al. (2012). Final Report Federal Regulation of Probiotics: An Analysis of the Existing Regulatory Framework and Recommendations for Alternative Frameworks. NIH Grant Number: 5R01HG005171-02. November 15, 118. URL: https://www.law.umaryland.edu/media/SOL/pdfs/Prog rams/Health-Law/FinalWhitePaper.pdf.

Huzhvynska, S. O. (2014). Vidbir molochnokyslykh bakterii dlia vyhotovlennia probiotychnykh preparative. Veterynarna medytsyna, 99, 196-201 (in Ukrainian).

Kalinichenko, S. V., Korotkykh, O. O., \& Tishchenko, I. Yu. (2016). Suchasni napriamky stvorennia ta udoskonalennia probiotykiv. Ukrainskyi biofarmatsevtychnyi zhurnal, 1(42), 4-10 (in Ukrainian).

Krasnykova, L. V., Hunkova, P. Y., \& Markelova, V. V. (2013). Mykrobyolohyia moloka y molochnыkh produktov. Laboratornyi praktykum. SPb.: Nyu Ytmo (in Russian).

Kushnir, I. I., Tsisaryk, O. Y., Shalovylo, S. H., Gutyj, B. V., Kushnir, G. V., Slyvka, I. M., \& Musiy L. Y. (2020). The ability of enterococci extracted from traditional Carpathian cheese bryndza to produce biologically active substances. Ukrainian Journal of Veterinary and Agricultural Sciences, 3(3), 15-19. doi: 10.32718/ujvas3-3.03.

Kushnir, I. I., Tsisaryk, O. Y., Slyvka, I. M., Musiy, L. Y., Kushnir, I. M., \& Semen, I. S. (2020). Growth intensity and antibacterial properties of Enterococcus faecium and Enterococcus durans strains isolated from traditional Carpathian brynza. Scientific Messenger of Lviv National University of Veterinary Medicine and Biotechnologies. Series: Agricultural sciences, 22(92), 42-49. doi: 10.32718/nvlvet-a9208.

Martinez, R. C. R. Anynaou, A. E., Albrecht., S. A., Schols, H. A., Martinis, E. C. P., Zoetendal, E. G., Venema, K., Saad, S. M. I., \& Smidt, H. (2011). In vitro evaluation of gastrointestinal survival of Lactobacillus amylovorus DSM 16698 alone and combined with galactooligosaccharides, milk and or Bifidobacterium animalis subsp. Lactis Bb-12. Int. J. Food Microbiol, 149(2), 152-158. doi: 10.1016/j.ijfoodmicro.2011.06.010.

Merlich, A. H., \& Limanska, N. V. (2016). Antahonistychna aktyvnist bakterii Lactobacillus plantarum, vydilenykh z roslynnykh dzherel Ukrainy ta Frantsii, proty fitopatohennykh bakterii. Mikrobiolohiia i biotekhnolohiia, 4, 71-85. doi: 10.18524/2307-4663.2016.4(36).86773 s.

Pokhylko, Yu. M., \& Kravchenko, N. O. (2016). Vplyv seredovyshcha kultyvuvannia na antahonistychnu aktyvnist molochnokyslykh bakterii. Silskohospodarska mikrobiolohiia, 24, 64-72 (in Ukrainian).

Shuhai, M. O. (2015). Antahonistychna aktyvnist yak kryterii vidboru molochnokyslykh bakterii u biotekhnolohii molochnykh fermentovanykh produktiv. Prodovolchi resursy. Seriia: Tekhnichni nauky, 4, 6974 (in Ukrainian).

Skybitskyi, V. H., Kozlovska, H. V., Ibatullina, F. Zh. et al. (2013). Metodychni rekomendatsii Z konstruiuvannia probiotykiv ta zastosuvannia yikh $\mathrm{u}$ praktytsi veterynarnoi medytsyny, K.: ZAT "Nichlava" (in Ukrainian).

Solonyna, N. L. (2013). Zhyttiezdatnist ta adhezyvni vlastyvosti probiotychnykh shtamiv mikrobiv, shcho vkhodiat do skladu liofilizovanykh komertsiinykh probiotykiv, vykorystovuvanykh u praktytsi. Annals of Mechnikov Institute, 1, 61-65 (in Ukrainian).

Slyvka, I. M, Tsisaryk, O. Y., Dronyk, G. V., \& Musiy, L. Y. (2018). Strains of lactic acid bacteria isolated from traditional Carpathian cheese. Regul. Mech. Biosyst., 9(1), 62-68. doi: 10.15421/021808.

Vamanu, E., \& Vamanu, A. (2010). Viability of the Lactobacillus rhamnosus IL1 strain in simulated gastrointestinal conditions. Int. J. Pharmacol, 6(5), 
732-737. doi: 10.3923/ijp.2010.732.737.

Vasyliuk, O. M., Kovalenko, N. K., \& Harmasheva, I. L. (2014). Antahonistychni vlastyvosti shtamiv Lactobacillus plantarum, izolovanykh iz tradytsiinykh fermentovanykh produktiv Ukrainy. Mikrobiol. Zhurnal, 76(3), 24-31 (in Ukrainian).

Voida, Yu. V., \& Solonyna, N. L. (2012). Mikroekolohiia liudyny i rol probiotychnykh preparativ $\mathrm{v}$ terapii hniinozapalnykh zakhvoriuvan $\mathrm{v}$ akusherstvi i hinekolohii. Annals of Mechnikov Institute, 2, 27-37 (in Ukrainian).

Irkitova, A. N. (2012). Ekoloho biolohichna otsinka shtamiv Lactobacillus Acidophilus, yaki vykorystovuiut $\mathrm{u}$ vyrobnytstvi probiotychnykh produktiv: avtoref. dys. na zdobuttja nauk. stupenja kandydata byol. nauk: spec. 03.02.03 "Mikrobiolohiia". Perm (in Russian). 